\title{
Daidzein and genistein contents of vegetables
}

\author{
J. Liggins ${ }^{1}$, L. J. C. Bluck ${ }^{2}$, S. Runswick ${ }^{1}$, C. Atkinson ${ }^{1}$, W. A. Coward ${ }^{2}$ and S. A. Bingham ${ }^{1} *$ \\ ${ }^{1}$ Medical Research Council, Dunn Human Nutrition Unit, Wellcome Trust/MRC Building, Hills Road, Cambridge CB2 2XY, \\ $U K$ \\ ${ }^{2}$ Medical Research Council, Human Nutrition Research, Downhams Lane, Milton Road, Cambridge CB4 IXJ, UK
}

(Received 11 November 1999 - Accepted 18 April 2000)

\begin{abstract}
Food samples ( $n$ 114) were prepared from vegetables commonly eaten in Europe. The glycosidic forms of the phyto-oestrogens daidzein and genistein were extracted from the dried foods into aqueous methanol. The isoflavones were quantified by GC-MS after hydrolytic removal of any conjugated carbohydrate. Completeness of extraction and any procedural losses of the isoflavones were accounted for using synthetic daidzin (7-O-glucosyl-4'-hydroxyisoflavone) and genistin (7-O-glucosyl-4'5-dihydroxyisoflavone) as internal standards. Of the 114 foods assayed, at a limit of quantification of $0 \cdot 1 \mu \mathrm{g} / \mathrm{kg}$ dry weight, forty-eight contained no detectable daidzein or genistein, forty-one contained less than $100 \mu \mathrm{g} / \mathrm{kg}$ of the two isoflavones combined and the remaining twenty-five contained more than this amount. Soyabean products contained between 470 and $1420 \mathrm{mg}$ (average of $960 \mathrm{mg}$ ) daidzein and genistein combined per $\mathrm{kg}$ wet weight of food, and legumes contained between 20 and $5750 \mu \mathrm{g} / \mathrm{kg}$ wet weight of food, with an average of $620 \mu \mathrm{g} / \mathrm{kg}$. Cooking by boiling in water caused a decrease in the daidzein and genistein content of food in twenty-four of twenty-eight foods. The extent of the decrease was variable and warrants further investigation. The present paper comprises the first comprehensive description of the content of daidzein and genistein in vegetables.
\end{abstract}

Phyto-oestrogens: Daidzein: Genistein

Phyto-oestrogens are a diverse group of naturally derived compounds that bear a structural resemblance to $17 \beta$ oestradiol $\left(\mathrm{E}_{2}\right)$ and which may protect against a wide range of conditions including breast, prostate, bowel and other forms of cancer, cardiovascular disease, osteoporosis and menopausal symptoms (Messina et al. 1994; Adlercreutz \& Mazur, 1997; Brzezinski et al. 1997; Kurzer \& Xu 1997; Bingham et al. 1998; Murkies et al. 1998). One of the proposed mechanisms for protection against these conditions is through their interaction with the oestrogen receptor (ER) and the subsequent perturbation of mechanisms controlled by $\mathrm{E}_{2}$. Two oestrogen receptors $(\mathrm{ER} \alpha$ and $\mathrm{ER} \beta$ ) have been identified in human subjects (Kuiper \& Gustafsson, 1997). The concentration of these receptors differs between tissues (Enmark et al. 1997) and possibly differs at the point of cell differentiation (Arts et al. 1997). The effect of phyto-oestrogens bound to ER remains to be elucidated. In vitro, physiological concentrations of phytooestrogens have been shown to act both agonistically (Kuiper et al. 1998) and antagonistically (Barkhem et al. 1998 ) to the $\mathrm{E}_{2}$-mediated transactivation of both $\mathrm{ER} \alpha$ and $\mathrm{ER} \beta$.
The health effects of phyto-oestrogens are, however, far more wide ranging than can be explained by interactions with ER. Genistein has been shown to be a potent protein tyrosine kinase inhibitor (Akiyama et al. 1987). Since that discovery, work on cell lines devoid of ER has revealed that phyto-oestrogens affect DNA topoisomerase II and ribosomal S6 kinase, which could explain their observed effects on cell cycle, differentiation, proliferation and apoptosis (Kurzer \& Xu, 1997). Phyto-oestrogens have also been proposed to offer antioxidant protection both directly (Ruiz Larrea et al. 1997) and indirectly by increasing the activity of antioxidant enzymes (Wei et al. 1995).

Soyabeans are a rich source of daidzein and genistein (Reinli \& Block, 1996), containing milligram quantities per $\mathrm{g}$ food. The isoflavones occur naturally in food as a variety of carbohydrate conjugates; three different glycosides have been identified in soyabean, all linked to C-7 of the isoflavone (Reinli \& Block, 1996). It is possible that many other different carbohydrate conjugates of isoflavones exist, but these have yet to be identified. Both daidzein and genistein have hydroxyl groups other than that on C-7 to which the known monosaccharides or other saccharides

\footnotetext{
Abbreviations: $\mathrm{E}_{2}, 17 \beta$-oestradiol; ER, oestrogen receptor.

* Corresponding author: Dr Sheila Bingham, tel +44 1223 252760, fax + 441223 252765, email Sheila.Bingham@mrc-dunn.cam.ac.uk
} 
could glycosidically bond. An analogous compound that could be considered is quercetin, a flavone found in tea, onions and other plants. A wide variety of glycosides of this compound have been identified, including a tetraglycoside (Manguro et al. 1996). Phyto-oestrogens such as daidzein and genistein are formed only after removal of their conjugated carbohydrate by bacteria in the gut (Chang \& Nair, 1995). Quantification of all the possible glycosides of these compounds would be time-consuming, even if authentic reference standards were available for comparison. The quantitative analysis is simplified by hydrolytically removing the carbohydrate and assaying only the aglycone compounds. A method of analysis using hydrolytic enzymes (cellulase) from Aspergillus niger with quantification via GC-MS was developed in this laboratory (Liggins et al. 1998). The concentration of daidzein and genistein in foodstuffs reported in the present paper can be used in future studies to assess the dietary intake of these compounds and their impact on health in epidemiological studies.

\section{Materials and methods}

\section{Collection and preparation of food samples}

Representative examples of each food were obtained by purchasing five samples of each food from different sources in the Cambridge area, typically two market stalls and three supermarkets. The food was weighed and any inedible matter was removed, weighed and discarded. If the food was normally eaten raw, each sample was placed in separate sealed plastic bags and frozen at $-20^{\circ} \mathrm{C}$ on the day of purchase for later freeze-drying. Freeze-drying typically took 1 week or more; thereafter the samples were weighed, milled with a kitchen grinder (model BL350; Kenwood Ltd, Havant, Hants., UK) and stored in separate airtight jars. The samples were desiccated further before assay. If the food was normally eaten cooked, each prepared sample was divided into half and half was prepared as described for the raw food samples. The remaining half of each sample was finely chopped and pooled with the other four samples. The foods were boiled for a defined time, drained, frozen and freeze-dried in the same manner as the raw foods. After freeze-drying the food samples were stored in the dark in airtight glass jars and assayed for isoflavones within 4 months.

\section{Quantification of daidzein and genistein in food}

The protocol for the extraction of daidzein and genistein from food and their subsequent quantification has been published elsewhere (Liggins et al. 1998). The present paper contains only a brief description of the assay method, including any slight modifications used for the assay of the foods.

All enzymes, reagents and chemicals were purchased from Sigma/Aldrich, Poole, Dorset, UK, unless otherwise stated. In order to inhibit losses of target compounds by adsorption, all glassware was silanised in a solution of dimethyldichlorosilane in heptane (1:20 ratio, v/v), followed by deactivation of excess reagent in methylated spirits and oven drying $\left(120^{\circ} \mathrm{C}\right)$.

A pooled example of each raw food type was prepared for assay by weighing $0.5 \mathrm{~g}$ of each of the five freeze-dried samples into a single $20 \mathrm{ml}$ screw-cap test-tube $(2.5 \mathrm{~g}$ in total). As the cooked foods had been pooled at an earlier stage, $1 \mathrm{~g}$ of the freeze-dried product was weighed into a similar tube. Five replicates of each of these pooled foods were prepared, one of which was assayed in advance of the other samples without internal standards to assess the approximate daidzein and genistein content. As reported elsewhere (Liggins et al. 1998), the synthetic glucosides daidzin (7-O-glucosyl-4'-hydroxyisoflavone) and genistin (7-O-glucosyl-4'5-dihydroxyisoflavone), both purchased from Plantech, Reading, Berks., UK, were used as the internal standards added to two of the replicates of each food type. The level of the standard was calculated to deliver the same concentration of daidzein and genistein as was already in the food. The two remaining replicate samples, containing no internal standard, were assayed as sample blanks. The difference in the average isoflavone concentration of the two samples containing standards and the sample blanks was used to calculate the recovery of the internal standards.

The isoflavone glycosides present in both the food and the internal standard were dissolved in at least $10 \mathrm{ml}$ aqueous methanol (4:1 ratio, v/v), using sonication for $15 \mathrm{~min}$ to break up cellular material, followed by overnight soaking in the solvent. Insoluble material was filtered off through a double layer of filter paper (Whatman no. 4 on top of Whatman no. 1), and any adsorbed isoflavones were washed through with fresh aqueous methanol $(4: 1, \mathrm{v} / \mathrm{v}$; $>5 \mathrm{ml})$. The alcohol in the filtrate was removed by evaporation under $\mathrm{N}_{2}$ to leave an aqueous extract, to which was added $5 \mathrm{ml} 0.1 \mathrm{M}$-acetate buffer, $\mathrm{pH} 5$, containing 100 units cellulase (Aspergillus niger; units as defined by Sigma, Poole, Dorset, UK). The mixture was incubated overnight at $37^{\circ} \mathrm{C}$ to remove the carbohydrate component of the isoflavone glycosides hydrolytically. The aglycone isoflavones were extracted from the aqueous hydrolysis solution by partitioning into ethyl acetate; three $2 \mathrm{ml}$ washes of ethyl acetate were combined. $2 \mathrm{ml}$ of the total was placed in a separate vial, and the solvent was evaporated under $\mathrm{N}_{2}$.

The dried extracts were derivatised by adding $0.6 \mathrm{ml}$ pyridine followed by $0.4 \mathrm{ml} \mathrm{N}$-(tert-butyldimethylsilyl)$\mathrm{N}$-methyltrifluoro-acetamide containing $1 \%(\mathrm{v} / \mathrm{v}) \quad \mathrm{N}$ (tert-butyldimethylsilyl)-chloride. After $1 \mathrm{~h}$ at room temperature, $3 \mu \mathrm{l}$ of the sample was injected onto the capillary column of the GC-MS (MD800; Thermoquest Ltd, Hemel Hempstead, Herts., UK). The GC-MS conditions used are described elsewhere (Liggins et al. 1998).

\section{Calculation of isoflavone quantities in food}

The daidzein and genistein concentration of each extracted sample was determined by comparison with pure authentic reference standards (Apin Chemicals Ltd, Abingdon, Oxon., UK), run simultaneously on the GC-MS. The recovery of the internal standards was used both to assess 


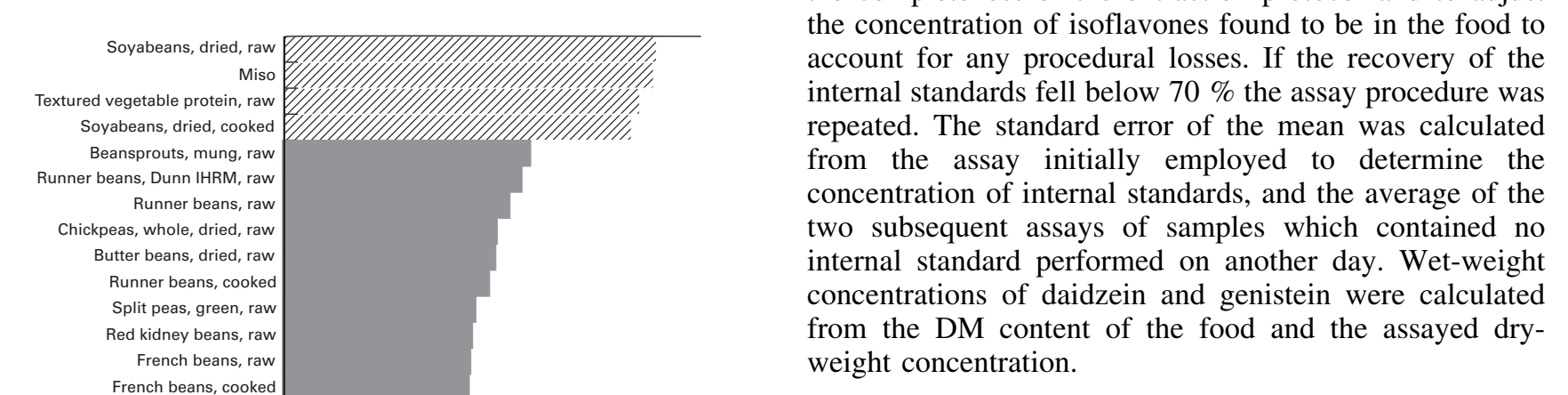

French sliced beans, frozen,

Chickpeas, whole, dried, cooked Haricot beans, raw

Lentils, red, split, dried, raw

Red kidney beans, cooked

Mung beans, dried, cooked Peas, dried, raw

French sliced beans, frozen, raw

Mung beans, dried, raw

Peas, dried, cooked

Haricot beans, cooked

Butter beans, dried, cooked

Potatoes, new, raw

Baked beans, heated

Okra, raw

Baked beans

Peas, frozen, raw

Peas, fresh, raw

Split peas, green, cooked

Lentils, red, split, dried, cooked

Celeriac, raw

Peas, frozen, cooked

Sweetcorn, tinned or frozen, raw

Potatoes, new, cooked

Celeriac, cooked

Tomato, raw

Sweetcorn, on cob, raw

Cabbage, Savoy, raw

Sweetcorn, tinned or frozen, cooked

Cabbage, red, cooked

Broad beans, raw

Turnip, raw

Peas, processed \& tinned

Sprouting broccoli, cooked

Salad onions

Sweetcorn, on cob, cooked

Mushroom, common, raw

Mushroom, common, cooked

Potato, old, raw

Sprouting broccoli, raw

Turnip, cooked

Pumpkin

Asparagus, raw

Aubergine, cooked

Aubergine, raw

Potato, old, cooked

Cabbage, white, cooked

Cucumber, with skin

Cabbage, white, raw

Cucumber, flesh only

Radish, raw

Chicory, raw

0.1

10

$1 \times 10^{3}$

$1 \times 10^{5}$

Concentration of daidzein and genistein combined ( $\log$ scale, $\mu \mathrm{g} / \mathrm{kg}$ wet weight of food)

Fig. 1. Comparison of the combined concentrations of daidzein and genistein in different foods vegetables and vegetable products

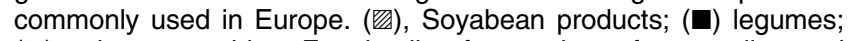
(囼), other vegetables. For details of procedures for sampling and analysis, see p. 718. the completeness of the extraction protocol and to adjust the concentration of isoflavones found to be in the food to account for any procedural losses. If the recovery of the internal standards fell below $70 \%$ the assay procedure was repeated. The standard error of the mean was calculated from the assay initially employed to determine the concentration of internal standards, and the average of the two subsequent assays of samples which contained no internal standard performed on another day. Wet-weight from the DM content of the food and the assayed dryweight concentration.

\section{Results}

Of the 114 assayed foods reported in the present paper, sixty-six contained measurable quantities of daidzein or genistein. Table 1 illustrates the daidzein and genistein content of vegetables and vegetable products (on both a dry weight and wet weight basis). The individual foods are listed in the order of their codes in the supplements to McCance and Widdowson's Composition of Foods (Holland et al. 1991). Table 1 includes the percentage recovery of the internal standards assayed with the samples; recoveries ranged from 70 to $109 \%$.

The results indicate that daidzein and genistein were found in a broad concentration range across a wide variety of vegetables. Fig. 1 compares the combined concentration of daidzein and genistein in the foods that contained these isoflavones. Three groups were evident. Foods derived from soyabean contained by far the highest concentration, $5 \times 10^{5}-14 \times 10^{5} \mu \mathrm{g}$ daidzein and genistein $/ \mathrm{kg}$ wet weight of food. The concentration observed in cooked soyabeans was two orders of magnitude higher than that in the nextrichest food (raw mung beansprouts; $6 \times 10^{3} \mu \mathrm{g} / \mathrm{kg}$ ). Mung beansprouts form part of the legume group highlighted in Fig. 1, which contained $2-6 \times 10^{3} \mu \mathrm{g}$ daidzein and genistein $/ \mathrm{kg}$ wet weight of food. The legume group, overall, contained more daidzein and genistein than the third group highlighted in Fig. 1 (other vegetables), but their concentration ranges overlapped, with the latter group containing up to $8 \mu \mathrm{g} / \mathrm{kg}$.

Cooking by boiling in water generally caused a decrease in the combined daidzein and genistein concentration (on a wet weight basis); however, in four foods, cooking increased these levels. The increase in these four foods is, however, relatively small and could be accounted for by experimental error. Of the twenty-four foods in which cooking decreased the daidzein and genistein concentration, nine lost at least $75 \%$ of the raw-weight value. Five contained very low amounts in the raw state and no isoflavone was detected after cooking. The remaining four foods that lost more than $75 \%$ of their daidzein and genistein on cooking were all dried legumes, soaked overnight in water before cooking. However, the cookingloss factors appear to be variable, as four other dried legumes, soaked overnight in water before cooking, retained more than $25 \%$ of the isoflavones (soyabeans $33 \%$, red kidney beans $55 \%$, haricot beans $65 \%$ and dried peas $84 \%$ ).

Table 2 compares the concentration of daidzein and 
Table 1. Daidzein $(\mathrm{Da})$ and genistein $(\mathrm{Ge})$ contents of vegetables and vegetable products commonly eaten in Europe*

(Mean values with their interassay standard errors)

\begin{tabular}{|c|c|c|c|c|c|c|c|c|c|c|c|c|}
\hline \multirow[b]{3}{*}{ M\&W code $†$} & \multirow[b]{3}{*}{ Vegetable } & \multirow[b]{3}{*}{ Date of assay } & \multirow{2}{*}{\multicolumn{2}{|c|}{$\begin{array}{l}\text { Recovery of internal } \\
\text { standards (\%) }\end{array}$}} & \multicolumn{4}{|c|}{ Concentration $(\mu \mathrm{g} / \mathrm{kg}$ dry weight $) \ddagger$} & \multirow[b]{3}{*}{ DM } & & & \\
\hline & & & & & \multicolumn{2}{|c|}{ (Da) } & \multicolumn{2}{|c|}{$(\mathrm{Ge})$} & & \multicolumn{3}{|c|}{ Mean concentration ( $\mu \mathrm{g} / \mathrm{kg}$ wet weight) $\ddagger$} \\
\hline & & & $\mathrm{Da}$ & $\mathrm{Ge}$ & Mean & SE & Mean & SE & & $\mathrm{Da}$ & $\mathrm{Ge}$ & Sum of $\mathrm{Da}$ and $\mathrm{Ge}$ \\
\hline 13-001 & Potatoes, new, raw & Dec 97 & 72 & 75 & 132 & 8 & 304 & 47 & 0.190 & $25 \cdot 1$ & 57.9 & 83 \\
\hline $13-003$ & Potatoes, new, cooked & Dec 97 & 75 & 78 & 55 & 12 & 147 & 13 & 0.186 & $10 \cdot 2$ & $27 \cdot 3$ & 37.5 \\
\hline $13-009$ & Potatoes, old, raw & Dec 97 & 79 & 83 & 28 & 5 & 47 & 12 & $1 \cdot 186$ & $5 \cdot 2$ & $8 \cdot 7$ & $13 \cdot 9$ \\
\hline 13-014 & Potatoes, old, cooked & Dec 97 & 72 & 79 & 5 & & 37 & 0 & 0.175 & 0.9 & 6.5 & $7 \cdot 4$ \\
\hline & Potatoes, red, cooked & Jun 98 & & & nd & & nd & & & nd & nd & \\
\hline $\mathrm{nc}$ & Potatoes, red, raw & Mar 98 & & & nd & & nd & & & nd & nd & \\
\hline $13-043$ & Baked beans & Jul 97 & & 102 & nd & & 228 & 64 & 0.278 & nd & 63.5 & 63.5 \\
\hline 13-044 & Baked beans, heated & Jun 97 & 93 & 76 & 51 & 11 & 201 & 94 & 0.276 & $14 \cdot 1$ & $55 \cdot 3$ & $69 \cdot 4$ \\
\hline 13-052 & Beansprouts, mung, raw & Feb 98 & 88 & 77 & $39 \times 10^{3}$ & 329 & $68 \times 10^{3}$ & 3134 & 0.054 & 2066 & 3670 & 5736 \\
\hline 13-064 & Broad beans, raw & Oct 97 & 72 & 96 & 74 & 8 & 59 & 12 & 0.183 & $13 \cdot 6$ & $10 \cdot 8$ & 24.4 \\
\hline 13-066 & Broad beans, cooked & Oct 97 & & & nd & & nd & & & nd & nd & \\
\hline $13-070$ & Butter beans, dried, raw & Mar 98 & 82 & 73 & 305 & 16 & 847 & 25 & 1.000 & 305 & 847 & 1152 \\
\hline 13-071 & Butter beans, dried, cooked & Mar 98 & 76 & 78 & 185 & 6 & 65 & 6 & 0.375 & 69.4 & 24.4 & 93.8 \\
\hline 13-074 & Chickpeas, whole, dried, raw & Mar 98 & 71 & 87 & 475 & 19 & 766 & 21 & 1.000 & 475 & 766 & 1241 \\
\hline 13-075 & Chickpeas, whole, dried, cooked & Mar 98 & & 83 & nd & & 578 & 66 & 0.418 & nd & 241.4 & 241.4 \\
\hline 13-081 & French beans, raw & Feb 98 & 96 & 87 & 1198 & 26 & 3372 & 67 & 0.084 & $100 \cdot 8$ & $283 \cdot 6$ & 384.4 \\
\hline $13-083$ & French beans, cooked & Dec 97 & 78 & 77 & 1151 & 189 & 3075 & 124 & 0.083 & 95.4 & 254.9 & $350 \cdot 3$ \\
\hline 13-085 & French sliced beans, frozen, cooked & Mar 98 & 92 & 81 & 686 & 42 & 1938 & & 0.097 & $66 \cdot 5$ & 188 & 254.5 \\
\hline $\mathrm{nc}$ & French sliced beans, frozen, raw & Mar 98 & 85 & 88 & 479 & 5 & 1362 & & 0.097 & $46 \cdot 5$ & $132 \cdot 1$ & $178 \cdot 6$ \\
\hline 13-086 & Haricot beans, raw & Mar 98 & 71 & 73 & 131 & 13 & 105 & 30 & 1.000 & 131 & 105 & 236 \\
\hline 13-087 & Haricot beans, cooked & Apr 98 & 93 & 91 & 186 & 17 & 173 & 7 & 0.425 & 79 & 73.5 & $152 \cdot 5$ \\
\hline 13-091 & Lentils, red, split, dried, raw & Mar 98 & 72 & 87 & 139 & 32 & 84 & 27 & 1.000 & 139 & 84 & 223 \\
\hline 13-092 & Lentils, red, split, dried, cooked & Mar 98 & 83 & 99 & 50 & 2 & 93 & 29 & 0.357 & $17 \cdot 8$ & $33 \cdot 2$ & 51 \\
\hline 13-096 & Mung beans, dried, raw & Apr 98 & 70 & 86 & 50 & 1 & 106 & 7 & 1.000 & 50 & 106 & 156 \\
\hline 13-099 & Mung beans, dried, cooked & Apr 98 & 72 & 80 & 154 & 43 & 399 & 36 & 0.373 & $57 \cdot 4$ & $148 \cdot 8$ & $206 \cdot 2$ \\
\hline 13-109 & Red kidney beans, raw & Mar 98 & 104 & 109 & 191 & 116 & 209 & 9 & 1.000 & 191 & 209 & 400 \\
\hline 13-110 & Red kidney beans, cooked & Mar 98 & 73 & 89 & 311 & 38 & 221 & 8 & 0.419 & $130 \cdot 2$ & 92.5 & $222 \cdot 7$ \\
\hline 13-112 & Runner beans, Dunn IHRM, raw & Mean $^{\S}$ & 96 & 95 & $23 \times 10^{3}$ & 532 & $31 \times 10^{3}$ & 2994 & 0.073 & 1672 & 2260 & 3932 \\
\hline 13-112 & Runner beans, raw & Jan 98 & 76 & 77 & $13 \times 10^{3}$ & 396 & $15 \times 10^{3}$ & 508 & 0.081 & 1036 & 1183 & 2219 \\
\hline 13-114 & Runner beans, cooked & Jan 98 & 72 & 78 & 7080 & 281 & 8860 & 616 & 0.056 & 396 & 495.9 & 891.9 \\
\hline 13-115 & Soyabeans, dried, raw & Apr 98 & 101 & 101 & $583 \times 10^{3}$ & $62 \times 10^{3}$ & $838 \times 10^{3}$ & $71 \times 10^{3}$ & 1.000 & $583 \times 10^{3}$ & $838 \times 10^{3}$ & $1421 \times 10^{3}$ \\
\hline $13-116$ & Soyabeans, dried, cooked & Apr 98 & 79 & 74 & $411 \times 10^{3}$ & $36 \times 10^{3}$ & $839 \times 10^{3}$ & $98 \times 10^{3}$ & 0.375 & $154 \times 10^{3}$ & $315 \times 10^{3}$ & $469 \times 10^{3}$ \\
\hline $\mathrm{nc}$ & Miso & Aug 97 & 88 & 79 & $594 \times 10^{3}$ & $5 \times 10^{3}$ & $673 \times 10^{3}$ & $9 \times 10^{3}$ & 0.998 & $593 \times 10^{3}$ & $672 \times 10^{3}$ & $1265 \times 10^{3}$ \\
\hline $17-081$ & Textured vegetable protein, raw & Oct 97 & 96 & 103 & $248 \times 10^{3}$ & $23 \times 10^{3}$ & $438 \times 10^{3}$ & $77 \times 10^{3}$ & 1.000 & $248 \times 10^{3}$ & $438 \times 10^{3}$ & $686 \times 10^{3}$ \\
\hline 13-127 & Peas, fresh, raw & Nov 97 & & 94 & nd & & 232 & 47 & 0.233 & nd & $54 \cdot 1$ & $54 \cdot 1$ \\
\hline 13-129 & Peas, fresh, cooked & Nov 97 & & & nd & & nd & & & nd & nd & \\
\hline $13-130$ & Peas, dried, raw & Apr 98 & 89 & 74 & 41 & 9 & 144 & 16 & 1.000 & $41 \cdot 0$ & 144 & 185 \\
\hline 13-131 & Peas, dried, cooked & Mar 98 & 91 & 74 & 32 & 10 & 381 & 9 & 0.375 & $12 \cdot 0$ & $142 \cdot 9$ & 154.9 \\
\hline 13-132 & Peas, frozen, raw & Apr 98 & 84 & 96 & nd & & 268 & 2 & 0.208 & nd & 55.7 & $55 \cdot 7$ \\
\hline 13-134 & Peas, frozen, cooked & Jul 97 & 101 & 83 & nd & & 215 & 40 & 0.194 & nd & $41 \cdot 7$ & $41 \cdot 7$ \\
\hline $\mathrm{nc}$ & Peas processed, tinned & Oct 97 & & 89 & nd & & 70 & & 0.271 & nd & $19 \cdot 0$ & $19 \cdot 0$ \\
\hline 13-141 & Split peas, green, raw & Mar 98 & 76 & 70 & 130 & 4 & 347 & 16 & 1.000 & 130 & 347 & 477 \\
\hline 13-142 & Split peas, green, cooked & Mar 98 & & 70 & nd & & 128 & 10 & 0.408 & nd & $52 \cdot 3$ & $52 \cdot 3$ \\
\hline 13-157 & Asparagus, raw & Oct 97 & 96 & 93 & 36 & 15 & 79 & 1 & 0.079 & $2 \cdot 8$ & $6 \cdot 2$ & $9 \cdot 0$ \\
\hline 13-158 & Asparagus, cooked & Oct 97 & & & nd & & nd & & & nd & nd & 0 \\
\hline 13-161 & Aubergine, raw & Oct 97 & 88 & 75 & 8 & 23 & 99 & 14 & 0.074 & 0.6 & $7 \cdot 3$ & 7.9 \\
\hline $\mathrm{nc}$ & Aubergine, cooked & Sep 97 & 105 & 90 & 50 & 37 & 105 & 27 & 0.054 & $2 \cdot 7$ & $5 \cdot 7$ & $8 \cdot 4$ \\
\hline
\end{tabular}


Table 1. continued

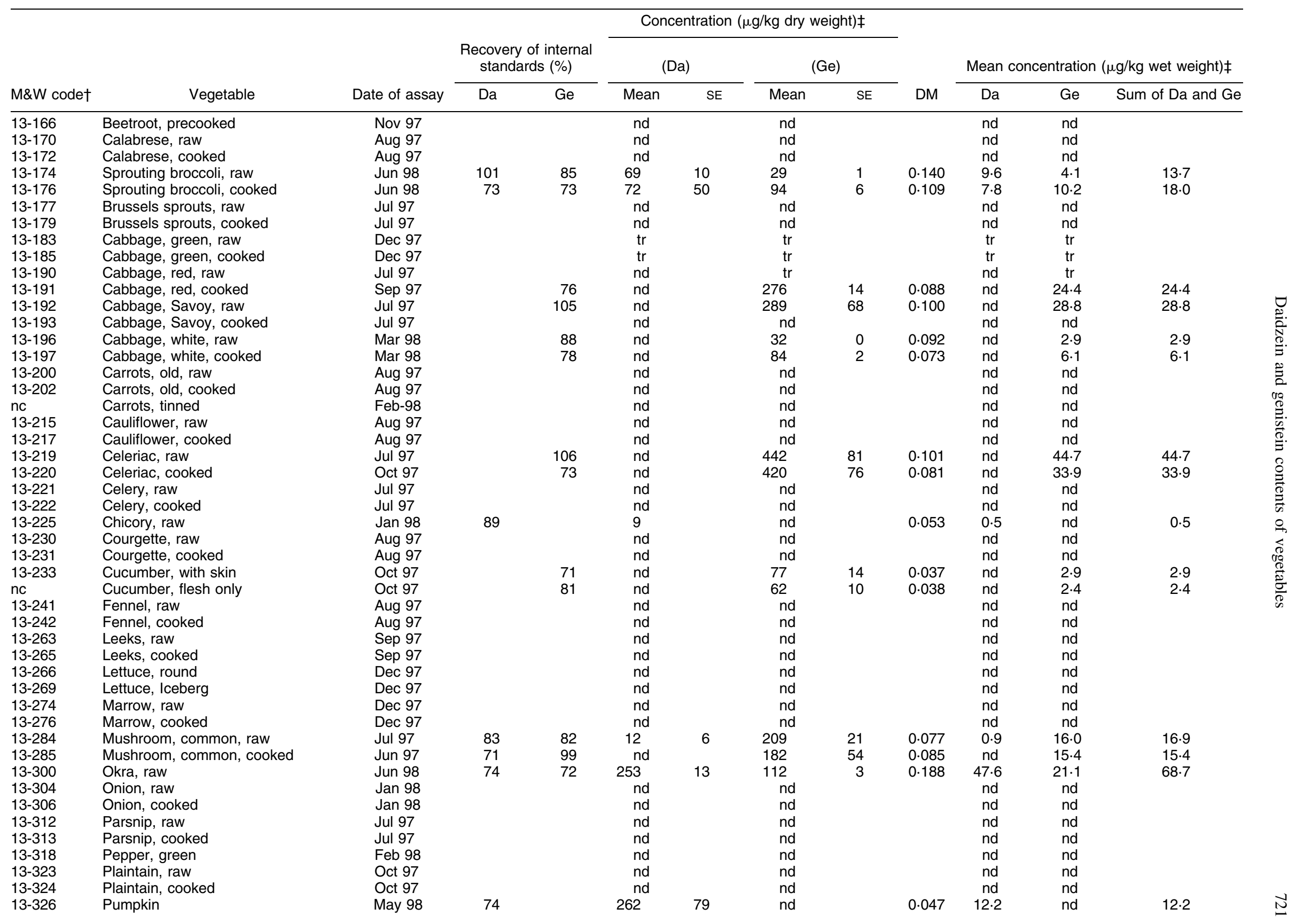


Table 1. continued

\begin{tabular}{|c|c|c|c|c|c|c|c|c|c|c|c|c|}
\hline \multirow[b]{3}{*}{ M\&W code $†$} & \multirow[b]{3}{*}{ Vegetable } & \multirow[b]{3}{*}{ Date of assay } & \multirow{2}{*}{\multicolumn{2}{|c|}{$\begin{array}{l}\text { Recovery of internal } \\
\text { standards (\%) }\end{array}$}} & \multicolumn{4}{|c|}{ Concentration $(\mu \mathrm{g} / \mathrm{kg}$ dry weight) $\ddagger$} & \multirow[b]{3}{*}{ DM } & & & \\
\hline & & & & & \multicolumn{2}{|c|}{ (Da) } & \multicolumn{2}{|c|}{$(\mathrm{Ge})$} & & \multicolumn{3}{|c|}{ Mean concentration ( $\mu \mathrm{g} / \mathrm{kg}$ wet weight) $\ddagger$} \\
\hline & & & $\mathrm{Da}$ & $\mathrm{Ge}$ & Mean & SE & Mean & SE & & $\mathrm{Da}$ & $\mathrm{Ge}$ & Sum of $\mathrm{Da}$ and $\mathrm{Ge}$ \\
\hline $13-330$ & Radish, raw & Nov 97 & 80 & 88 & nd & & 45 & 4 & 0.051 & nd & $2 \cdot 3$ & $2 \cdot 3$ \\
\hline $13-343$ & Spinach, raw & Nov 97 & & & nd & & nd & & & nd & nd & \\
\hline $13-345$ & Spinach, cooked & Nov 97 & & & nd & & nd & & & nd & nd & \\
\hline $13-348$ & Spring greens, raw & Jul 97 & & & nd & & nd & & & nd & nd & \\
\hline $13-350$ & Spring greens, cooked & Jul 97 & & & nd & & nd & & & nd & nd & \\
\hline $13-352$ & Salad onions & Jul 97 & & 100 & nd & & 187 & 20 & 0.094 & nd & $17 \cdot 6$ & $17 \cdot 6$ \\
\hline $13-359$ & Swede, raw & Aug 97 & & & nd & & nd & & & nd & nd & \\
\hline $13-361$ & Swede, cooked & Aug 97 & & & nd & & nd & & & nd & nd & \\
\hline $13-362$ & Sweet potato, raw & Aug 97 & & & nd & & nd & & & nd & nd & \\
\hline $13-364$ & Sweet potato, cooked & Aug 97 & & & nd & & nd & & & nd & nd & \\
\hline $13-368$ & Sweetcorn, on cob, raw & Dec 97 & 93 & 73 & nd & & 134 & 2 & 0.235 & nd & 31.5 & 31.5 \\
\hline $13-370$ & Sweetcorn, on cob, cooked & Jun 98 & 75 & 86 & 29 & 10 & 45 & 8 & 0.235 & $6 \cdot 8$ & $10 \cdot 6$ & 17.4 \\
\hline $\mathrm{nc}$ & Sweetcorn, tinned or frozen, cooked & Jun 98 & 93 & 77 & 40 & 5 & 66 & 2 & 0.262 & 10.5 & $17 \cdot 3$ & $27 \cdot 8$ \\
\hline $\mathrm{nc}$ & Sweetcorn, tinned or frozen, raw & Dec 97 & 79 & 82 & 74 & 25 & 59 & 7 & 0.308 & $22 \cdot 8$ & $18 \cdot 2$ & $41 \cdot 0$ \\
\hline $13-384$ & Tomato, raw & Aug 97 & 72 & 80 & nd & & 480 & 31 & 0.068 & nd & 32.5 & 32.5 \\
\hline $13-389$ & Turnip, raw & Mar 98 & 91 & 79 & 165 & 15 & 47 & 3 & 0.091 & $15 \cdot 0$ & 4.3 & $19 \cdot 3$ \\
\hline $13-391$ & Turnip, cooked & Mar 98 & 77 & 87 & 94 & 9 & 72 & 78 & 0.077 & 7.3 & $5 \cdot 6$ & $12 \cdot 9$ \\
\hline $13-396$ & Salad cress & Oct 97 & & & nd & & nd & & & nd & nd & \\
\hline $13-396$ & Watercress & Nov 97 & & & nd & & nd & & & nd & nd & \\
\hline
\end{tabular}

M\&W code, food coding as in Holland et al. (1991); nc, not coded in Holland et al. (1991); nd, not detected; tr, trace.

* For details of procedures for sampling and analysis, see p. 718.

† Items are listed in the order of their appearance in Holland et al. (1991).

ids; for details, see p. 724

$\S$ This food was separately analysed twenty-four times over a period of 2 years and the values shown are an average of those assays. 
Table 2. Daidzein and genistein concentrations $(\mu \mathrm{g} / \mathrm{kg})$ for vegetables and vegetable products determined in the present study compared with those previously reported ${ }^{*}$

\begin{tabular}{|c|c|c|c|c|}
\hline \multirow[b]{2}{*}{ Food } & \multicolumn{2}{|c|}{ Present study } & \multicolumn{2}{|c|}{ Other studies } \\
\hline & Daidzein & Genistein & Daidzein & Genistein \\
\hline Soyabeans, raw & $58 \times 10^{4}$ & $84 \times 10^{4}$ & $33 \times 10^{4} \dagger$ & $48 \times 10^{4} \dagger$ \\
\hline Soyabeans, raw (ww) & $58 \times 10^{4}$ & $84 \times 10^{4}$ & $54 \times 10^{4} \ddagger$ & $84 \times 10^{4} \ddagger$ \\
\hline Soyabeans, boiled (ww) & $15 \times 10^{4}$ & $32 \times 10^{4}$ & $20 \times 10^{4} \ddagger$ & $31 \times 10^{4} \ddagger$ \\
\hline Miso & $59 \times 10^{4}$ & $67 \times 10^{4}$ & $14 \times 10^{4} \S$ & $15 \times 10^{4} \S$ \\
\hline Miso (ww) & $59 \times 10^{4}$ & $67 \times 10^{4}$ & $19 \times 10^{4} \S$ & $31 \times 10^{4} \S$ \\
\hline Beansprouts (mung) & $39 \times 10^{3}$ & $68 \times 10^{4}$ & $\begin{array}{c}8 \times 10^{3} \S \\
\mathrm{nd} \|\end{array}$ & $\begin{array}{c}19 \times 10^{3} \S \\
\mathrm{nd} \|\end{array}$ \\
\hline Broad bean & 70 & 60 & $240 \dagger$ & $\operatorname{tr} \dagger$ \\
\hline Broccoli, calabrese & nd & nd & $50 \S$ & $70 \S$ \\
\hline Carrot & nd & nd & $20 \S$ & $20 \S$ \\
\hline Cranberry & 50 & 210 & $0 \S$ & $0 \S$ \\
\hline Chickpeas & 480 & 770 & $110 \S$ & $760 \S$ \\
\hline Green split pea & 130 & 350 & $\begin{array}{l}80 \dagger \\
73 \times 10^{3} \|\end{array}$ & tr† \\
\hline Haricot beans & 130 & 110 & $140 \dagger$ & $4 \times 10^{3} \dagger$ \\
\hline Oatmeal & nd & nd & $0 \S$ & $0 \S$ \\
\hline Mung beans & 50 & 110 & $\begin{array}{c}100 \S \\
\text { nd\| }\end{array}$ & $\begin{array}{l}4 \times 10^{3} \S \\
\mathrm{nd} \|\end{array}$ \\
\hline Mushroo & 10 & 210 & $200 \S$ & $1170 \S$ \\
\hline Red kidney beans & 190 & 210 & $80 \dagger$ & $70 \dagger$ \\
\hline
\end{tabular}

nd, not detected; tr, isoflavone were identified but could not be quantified; ww, wet weight.

* Concentrations expressed on a dry weight basis, unless otherwise indicated. † Mazur et al. (1998).

‡ Reinli \& Block (1996)

$\S$ Adlercreutz \& Mazur (1997).

II Franke et al. (1994).

genistein reported here with concentrations for the same foods published by other authors. The results in Table 2 largely concur with published values; however, those for mung beansprouts and green split peas differ from those of Franke et al. (1994), but concur with those reported by other researchers (Adlercreutz \& Mazur 1997; Mazur et al. 1998).

\section{Discussion}

The foods selected for the present study were chosen because they are staple ingredients of the UK diet. To date, the study of the dietary intakes of daidzein and genistein has been restricted mainly to soyabean products and other legumes. These foods, however, form only a small part of the 'Western diet', and in order to assess fully the dietary impact of phyto-oestrogens on the health of a population it is necessary to know their concentrations in other foods. The data reported here are not intended to provide a definitive phyto-oestrogen concentration for a given food, since natural variation could be considerable, as in soyabean (Wang \& Murphy, 1994; Reinli \& Block, 1996; Gang et al. 1997; Lers et al. 1998; Mazur et al. 1998). The concentrations reported here are derived from pooled samples of each food. No attempt has been made to measure the variation in concentration within the pooled samples, due to the extensive work necessary to obtain such data.

The analytical method employed for the quantification of daidzein and genistein in food was developed using a varied mixture of bleached white wheat flour and soyabean flour of known isoflavone content (Liggins et al. 1998). The soyabean flour had been analysed independently without hydrolysis, in such a way that the percentages of the three main known glycosides and the aglycone in soyabean flour were known (glucose 45, malonyl-glucose 23 , acetyl-glucose 30 , aglycone 2). The same soyabean flour was used as a reference material to ensure the quality of the assay procedure over time, using the recommendations made by Thompson \& Wood (1995). To ensure that the assayed concentration reflected the actual content of the food, the completeness of hydrolysis and yield of aglycone isoflavones from each food was checked by the inclusion of glycosidic internal standards, at an aglycone concentration equal to that already present in the food. The recovery of the internal standards was used to normalise the results for different losses of the target compounds between assays, provided that the recovery of the internal standards was greater than $70 \%$; if the recovery was less than this amount, the results were rejected and the assay repeated.

The assay procedure employed for the present study could have been improved if other synthetic glycosidic conjugates of daidzein and genistein had been included with each food, together with the daidzin and genistin. Inclusion of such a variety of carbohydrate conjugates would give greater insight into the completeness of hydrolysis of each glycoside by cellulase. The assay used here relies on the assumption that all glycosides of daidzein and genistein are hydrolysed as completely as the synthetic daidzin and genistin added to each food. For the known carbohydrate conjugates present in soyabean (glucose, malonyl-glucose and acetyl-glucose) the assumption is valid. The hydrolytic assay procedure used here returned a total concentration of daidzein and genistein in soyabean equivalent to the sum of the three glucosides assayed independently (Liggins et al. 1998).

The foods collected for the present study could have been assayed using a non-glycolytic preparative procedure and quantification of the three known glycosides of daidzein and genistein. Such an approach would have been appropriate had the foods been of soyabean origin, where those glycosides were probably the predominant forms. However, the foods used here were not largely of soyabean origin, and the nature of the carbohydrate conjugated to the isoflavones was unknown. In foods where the predominant carbohydrate conjugate was not one of the three found in soyabean, quantification of just the three known glycosides would have underestimated their total daidzein and genistein content. It was, therefore, logical to employ an assay with a glycolytic step, to liberate the aglycone daidzein and genistein from all glycosides present in a food and to report the total content of each food. However, if some of these glycosides were not hydrolysed as completely as the synthetic daidzein and genistein that were added to each food, then the total concentrations may be underestimates. At present, however, lack of understanding of the nature of the glycosides and of the effect of the matrix on hydrolysis prevents further resolution of this problem.

The analytical data presented in Table 1 indicate that there are a number of possible sources of dietary daidzein and genistein, and that many and varied components of the 
Table 3. Published concentrations ( $\mu \mathrm{g} / 24 \mathrm{~h}$ ) of daidzein and genistein excreted by human subjects consuming Western-style diets of their own choice

\begin{tabular}{|c|c|c|c|c|c|}
\hline Diet & Sex of participants & Sample & Daidzein & Genistein & Reference \\
\hline Omnivorous & Male & Urine & 48 & 50 & Adlercreutz et al. (1991) \\
\hline Omnivorous & Female & Urine & 33 & 22 & Cassidy et al. (1991) \\
\hline Omnivorous & Female & Faeces & 17 & 3 & Adlercreutz et al. (1995) \\
\hline Lactovegetarian & Female & Faeces & 160 & 51 & Adlercreutz et al. (1995) \\
\hline Omnivorous & Male & Urine & 144 & 42 & Hutchins et al. (1995) \\
\hline Omnivorous & Male and female & Urine & 1065 & 297 & Kelly et al. (1995) \\
\hline Omnivorous & Female & Urine & 203 & 65 & Horn-Ross et al. (1997) \\
\hline Omnivorous & Male & Urine & 266 & 61 & Karr et al. (1997) \\
\hline
\end{tabular}

human diet contain phyto-oestrogens. The richest sources are of soyabean origin, with concentrations two orders of magnitude higher than those in the next-richest grouping, the legumes. The legumes contain a wide concentration range of the isoflavones, overlapping that of other vegetables. The findings of the present study thus support those of previous studies illustrating the daidzein and genistein content of leguminous samples (Mazur et al. 1998).

The concentrations of daidzein and genistein in a limited number of other foods are compared with other published values in Table 2. Slight differences in concentration are probably due to natural variation, possibly compounded by differences in the techniques used for quantification. However, for the majority of the foods indicated in Table 2 , the results presented here compare well with those published elsewhere. Two exceptions are mung beansprouts and green split peas: the results we report for green split peas agree with those of Adlercreutz \& Mazur (1997) and of Mazur et al. (1998), who (like ourselves) used a GC-MS-based method of quantification; however, our results differ from those reported by Franke et al. (1994), who used HPLC combined with spectrophotometry. In the absence of a common reference material it is not known whether the high concentration of daidzein found in green split peas by Franke et al. (1994) is due to a genuine difference in the material tested. The difference in isoflavone concentration between mung beans and mung beansprouts in Table 1 seems to indicate that major changes may occur during sprouting. This factor might explain the difference between laboratories in concentrations of the isoflavones (Table 2).

A number of studies have been undertaken to investigate the concentration of daidzein and genistein in biological samples. Table 3 illustrates urine and faecal excretion of isoflavones in five studies of free-living individuals and in two studies where the diet was controlled. In the study by Karr et al. (1997), the subjects were supplied for 9 d with a soyabean-free diet; in the investigation by Kelly et al. (1995), individuals were asked to avoid legumes for 1 week before the study. The results of the studies illustrated in Table 3 support the findings, outlined in Table 1, that dietary sources of daidzein and genistein, other than soyabean, exist. The presence of daidzein and genistein in the plasma and prostatic fluid of free-living individuals from Australia (Morton et al. 1994), Portugal and the UK (Morton et al. 1997a,b) would also support such findings. The plasma or urine concentrations of daidzein and genistein populations regularly consuming soyabean as part of their normal diet are, however, considerably greater (Dalais et al. 1998; Maskarinec et al. 1998; Seow et al. 1998).

The present paper has concentrated on quantifying two phyto-oestrogens in a selection of foods eaten in Europe, for inclusion in databases of food composition. In this respect, identification of foods that contain no daidzein and genistein is equally important. Future research should include quantification of other phyto-oestrogens, in the foods listed here and also in other foods.

\section{Acknowledgements}

This work was supported by the UK Medical Research Council, the Ministry of Agriculture, Fisheries and Food (contract FS2034) and the US Army (contract DAMD1797-1-7028). The authors would like to thank the following: Dr P. Murphy of Iowa State University, Des Moines, IA, USA for the independent analysis of the soyabean flour; also Mrs M. Harding, Mr K. Jones, Miss N. Duffy, Miss E. Neeley, Miss C. Jeffray, Miss L. Keppel, Miss A. Lam and Miss S. Barker for their technical assistance.

\section{References}

Adlercreutz H, Fotsis T, Bannwart C, Wahala K, Brunow G \& Hase T (1991) Isotope-dilution gas-chromatographic massspectrometric method for the determination of lignans and isoflavonoids in human urine, including identification of genistein. Clinica Chimica Acta 199, 263-278.

Adlercreutz H, Fotsis T, Kurzer MS, Wahala K, Makela T \& Hase $\mathrm{T}$ (1995) Isotope-dilution gas-chromatographic mass-spectrometric method for the determination of unconjugated lignans and isoflavonoids in human feces, with preliminary results in omnivorous and vegetarian women. Analytical Biochemistry 225, 101-108.

Adlercreutz H \& Mazur W (1997) Phyto-oestrogens and Western diseases. Annals of Medicine 29, 95-120.

Akiyama T, Ishida J, Nakagawa S, Ogawara H, Watanabe S, Itoh N, Shibuya M \& Fukami Y (1987) Genistein, a specific inhibitor of tyrosine-specific protein kinases. Journal of Biological Chemistry 262, 5592-5595.

Arts J, Kuiper G, Janssen J, Gustafsson JA, Lowik C, Pols HAP \& VanLeeuwen J (1997) Differential expression of estrogen receptors alpha and beta mRNA during differentiation of human osteoblast SV-HFO cells. Endocrinology 138, 50675070.

Barkhem T, Carlsson B, Nilsson Y, Enmark E, Gustafsson JA \& Nilsson S (1998) Differential response of estrogen receptor alpha and estrogen receptor beta to partial estrogen agonists/ antagonists. Molecular Pharmacology 54, 105-112. 
Bingham SA, Atkinson C, Liggins J, Bluck L \& Coward A (1998) Plant oestrogens: Where are we now? British Journal of Nutrition 79, 393-406.

Brzezinski A, Adlercreutz H, Shaoul R, Rosler A, Shmueli A, Tanos V \& Schenker JG (1997) Short-term effects of phytoestrogen-rich diet on postmenopausal women. Menopause 4, 89-94.

Cassidy A, Bingham S, Setchel K \& Watson D (1991) Urinary plant oestrogen excretion in post menopausal women. Proceedings of the Nutrition Society 50,105A.

Chang YC \& Nair MG (1995) Metabolism of daidzein and genistein by intestinal bacteria. Journal of Natural Products $\mathbf{5 8}$, 1892-1896.

Dalais FS, Rice GE, Wahlqvist ML, HsuHage BHH \& Wattanapenpaiboon N (1998) Urinary excretion of isoflavonoid phytoestrogens in Chinese and Anglo-Celtic populations in Australia. Nutrition Research 18, 1703-1709.

Enmark E, PeltoHuikko M, Grandien K, Lagercrantz S, Lagercrantz J, Fried G, Nordenskjold M \& Gustafsson JA (1997) Human estrogen receptor beta-gene structure, chromosomal localization, and expression pattern. Journal of Clinical Endocrinology and Metabolism 82, 4258-4265.

Franke AA, Custer LJ, Cerna CM \& Narala KK (1994) Quantitation of phytoestrogens in legumes by HPLC. Journal of Agricultural and Food Chemistry 42, 1905-1913.

Gang DR, Dinkova-Kostova AT, Davin LB \& Lewis NG (1997) Phylogenetic links in plant defense systems: lignans, isoflavonoids, and their reductases. ACS Symposium Series 658, 58-89.

Holland B, Unwin ID \& Buss DH (1991) Vegetables and Spices: Fifth Supplement to McCance and Widdowson's The Composition of Foods, 4th ed. Cambridge: Royal Society of Chemistry and Ministry of Agriculture, Fisheries and Food.

Horn-Ross PL, Barnes S, Kirk M, Coward L, Parsonnet J \& Hiatt RA (1997) Urinary phytoestrogen levels in young women from a multiethnic population. Cancer Epidemiology, Biomarkers and Prevention 6, 339-345.

Hutchins AM, Slavin JL \& Lampe JW (1995) Urinary isoflavonoid phytoestrogen and lignan excretion after consumption of fermented and unfermented soy products. Journal of the American Dietetic Association 95, 545-551.

Karr SC, Lampe JW, Hutchins AM \& Slavin JL (1997) Urinary isoflavonoid excretion in humans is dose dependent at low to moderate levels of soy-protein consumption. American Journal of Clinical Nutrition 66, 46-51.

Kelly GE, Joannou GE, Reeder AY, Nelson C \& Waring MA (1995) The variable metabolic response to dietary isoflavones in humans. Proceedings of the Society for Experimental Biology and Medicine 208, 40-43.

Kuiper G \& Gustafsson JA (1997) The novel estrogen receptorbeta subtype: potential role in the cell- and promoter-specific actions of estrogens and anti-estrogens. FEBS Letters 410, 8790.

Kuiper G, Lemmen JG, Carlsson B, Corton JC, Safe SH, VanderSaag PT, VanderBurg P \& Gustafsson JA (1998) Interaction of estrogenic chemicals and phytoestrogens with estrogen receptor beta. Endocrinology 139, 4252-4263.

Kurzer MS \& Xu X (1997) Dietary phytoestrogens. Annual Review of Nutrition 17, 353-381.

Lers A, Burd S, Lomaniec E, Droby S \& Chalutz E (1998) The expression of a grapefruit gene encoding an isoflavone reductase-like protein is induced in response to UV irradiation. Plant Molecular Biology 36, 847-856.

Liggins J, Bluck LJC, Coward WA \& Bingham SA (1998) Extraction and quantification of daidzein and genistein in food. Analytical Biochemistry 264, 1-7.

Manguro LOA, Midiwo JO \& Kraus W (1996) A new flavonol tetraglycoside from Myrsine africana leaves. Natural Product Letters 9, 121-126.

Maskarinec G, Singh S, Meng LX \& Franke AA (1998) Dietary soy intake and urinary isoflavone excretion among women from a multiethnic population. Cancer Epidemiology, Biomarkers and Prevention 7, 613-619.

Mazur WM, Duke JA, Wahala K, Rasku S \& Adlercreutz H (1998) Isoflavonoids and lignans in legumes: nutritional and health aspects in humans. Journal of Nutritional Biochemistry 9, 193-200.

Messina MJ, Persky V, Setchell KDR \& Barnes S (1994) Soy intake and cancer risk: a review of the in vitro and in vivo data. Nutrition and Cancer 21, 113-131.

Morton MS, Chan PSF, Cheng C, Blacklock N, Matos-Ferreira A, Abranches-Monteiro L, Correia R, Lloyd S \& Griffiths K (1997a) Lignans and isoflavonoids in plasma and prostatic fluid in men: samples from Portugal, Hong Kong, and the United Kingdom. Prostate 32, 122-128.

Morton MS, Matos-Ferreira A, Abranches-Monteiro L, Correia R, Blacklock N, Chan PSF, Cheng C, Lloyd C, Chiehping W \& Griffiths K (1997b) Measurement and metabolism of isolflavonoids and lignans in the human male. Cancer Letters 114, $145-151$.

Morton MS, Wilcox G, Wahlqvist ML \& Griffiths K (1994) Determination of lignans and isoflavonoids in human female plasma following dietary supplementation. Journal of Endocrinology 142, 251-259.

Murkies AL, Wilcox G \& Davis SR (1998) Phytoestrogens. Journal of Clinical Endocrinology and Metabolism 83, 297303.

Reinli K \& Block G (1996) Phytoestrogen content of foods - a compendium. Nutrition and Cancer 26, 123-148.

Ruiz Larrea MB, Mohan AR, Paganga G, Miller NJ, Bolwell GP \& Rice Evans CA (1997) Antioxidant activity of phytoestrogenic isoflavones. Free Radical Research 26, 63-70.

Seow A, Shi CY, Franke AA, Hankin JH, Lee HP \& Yu MC (1998) Isoflavonoid levels in spot urine are associated with frequency of dietary soy intake in a population-based sample of middle-aged and older Chinese in Singapore. Cancer Epidemiology, Biomarkers and Prevention 7, 135-140.

Thompson M \& Wood R (1995) Harmonised guidelines for internal quality control in analytical chemistry laboratories. Pure and Applied Chemistry 67, 649-666.

Wang H \& Murphy PA (1994) Isoflavone composition of American and Japanese soybeans in Iowa: effects of variety, crop year, and location. Journal of Agricultural and Food Chemistry 42, 1674-1677.

Wei H, Bowen R, Cai Q, Barnes S \& Wang Y (1995) Antioxidant and antipromotional effects of the soybean isoflavone genistein. Proceedings of the Society for Experimental Biology and Medicine 208, 124-130. 